\title{
Review of Criminalisation and Advanced Marginality: Critically Exploring the Work of Loïc Wacquant
}

\author{
MELISSA DEAREY \\ University of Hull, United Kingdom
}

Criminalisation and Advanced Marginality: Critically Exploring the Work of Loïc Wacquant

Edited by Peter Squires and John Lea, Bristol, UK: The Policy Press, 2012, ISBN: 9781447300014

This book is presented as "the first full-length critical and interdisciplinary assessment of Loïc Wacquant's work in English." Apart from the final chapter, most of the eleven chapters comprising the book originated in a conference devoted to the work of Wacquant organized by the University of Brighton Criminology Group in September 2010. The final chapter is a commentary and response to these papers by Wacquant himself, an interesting and unusual contribution to an edited volume of its kind.

Though the book is described as an interdisciplinary study, it is perhaps advisable to qualify this for the general reading audience. As the organization of the original conference indicates, the approach across the chapters is distinctively social scientific, to be sure sociological if not overtly criminological. While of course those of us in the criminology community would commonly see ourselves as embracing interdisciplinarity within the academy - and to some extent this would be justified - others (including myself, who came to criminology from the humanities) would find this claim perhaps a little exaggerated. Certainly there is a wealth of scholarship in terms of relating many of Wacquant's theses to the classical and critical traditions of criminology, making this a most useful resource for teaching criminological and social theory, and indeed penology in particular. While there is a good deal of philosophical theory referenced throughout and across the chapters, and a chapter focusing on women and gender, generally speaking, this book 
is firmly located in the terrain of social scientific research and social theory. No bad thing, necessarily, but something that readers who have other and broader interpretations of interdisciplinary approaches might wish to bear in mind.

Also it is worth noting that the works of Wacquant focused and commented upon within this volume are Punishing the Poor (2009) and Urban Outcasts (2007). Again, two important works by Wacquant, though in the current intellectual climate of interdisciplinary scholarship, it might have been interesting and innovatory to have a chapter more thoroughly devoted to Wacquant's work on the body and carnality within and without the social sciences (as for example in his work on boxing), as these represent key themes in the development of interdisciplinary scholarship. Having said this, the body does on occasion feature en passant, as for example in Lynda Measor's citation of Wacquant's perception of "blemished bodies" being emblematic of "scorched communities" in the chapter on gender and cultures of resistance, and in John J. Roger's interrogation of the potent metaphors of the body in the "social bulimia" (borrowing Jock Young's phrase) of global market capitalism.

The main theme that emerges in reading across the contributions contained in this essay is the emphasis on critical. While there is evidence of some critical assessment of Wacquant's work in light of recent social events, for me the criticality concerned very much echoes what in the advent of the age of administrative criminology relates to the critical (read "radical") tradition in criminology. And from where I am standing, as a teacher of social theory, this is a very good thing. Too long the critical/radical tradition in criminology has been seen as a depleted and dead force, an anachronism of criminological theory that has been superseded and has faded into obscurity along with its hippy constituency. Of course, as witnessed by its heirs in anarchic criminology, this is not the case; at the same time, it is welcome to see this tradition of criminological/sociological analysis of the penal/ welfare state emerge from its shadows at the "margins" in the academy, and begin its task by unapologetically and fundamentally adopting a thorough critique of neoliberalism. This certainly echoes and indeed contributes to broader changes in the discipline of criminology that incorporates "green" crime and issues pertaining to crimes committed by omission or commission by the institutional organizations of the state and the nefarious interests of global corporations, resulting in the widespread suffering to individuals and communities and indeed proliferation of "the precariat" and harm to the environment through new mechanisms of coercion and social control. For this alone, this volume is to be welcomed as in many ways a refreshing reminder and change of voice. At the same time, it is debatable how appealing this book will be to those within the administrative school of thought and their compatriots in terms of its fundamental intellectual, ideological and political premises, but that is another matter. While some will find such views polemical at best, outdated or biased at worst, they are still powerful and worthy of broadcast and dissemination. 